\title{
New Definition of a Sustainable Enterprise
}

\author{
Barteomiej Brach, Marcin Gul, Grzegorz Kawecki \\ Institute of Human Capital, Collegium of Business Administration, \\ SGH Warsaw School of Economics
}

\begin{abstract}
The interest in the concept of sustainable development is a form of a scientific response to the challenges of transforming economies, growing expectations of local communities and societies and environmental degradation. Despite numerous definitions of sustainable development, the literature lacks a widely recognised definition of an entity that operates in a sustainable way - a sustainable enterprise. The literature review identified two definition gaps: 1) the lack of defined boundaries within which a company must operate in order to be called sustainable, and 2) the lack of a definition of the relationship between the areas in which sustainability is assessed. The authors of the article propose a new definition of a sustainable enterprise. Moreover, they give examples of organisations that, although in a selected area they carry out sustainable activities, they cannot be called sustainable.
\end{abstract}

Keywords: sustainable organisation, sustainable enterprise, sustainable development, stakeholder theory

JEL Classification Code: M140 


\section{Introduction}

The dynamics of changes in the modern economy caused, among others, by the degradation of the natural environment and the ageing of the society, forces companies to evaluate and change their objectives. The number of 'enterprises with a mission' and those operating in accordance with the principles of sustainable development is increasing. Examples of organisations developing in a socially and environmentally friendly way include Ikea, Unilever, Patagonia, Natura or Danone (GlobeScan - SustainAbility, 2019). These companies, leaders of the Sustainability Leaders ranking, remain a model and point of reference for changes aimed at greater sustainability of other companies. The question arises, however, when companies following this pattern can be considered sustainable. The authors of the article claim that the current definitions of a sustainable enterprise do not provide a clear answer to this question and thus remain difficult to use in business. It is, therefore, appropriate to look at the concept of sustainable development and try to define on its basis the definition of a sustainable enterprise so that it sets clear boundaries to its activities.

\section{The concept of sustainable development in the context of the stakeholder theory}

The term stakeholder was first used by R.E. Freeman (1979), who derived it from the word stake, meaning something relevant to a case or a person. Freeman defined the term stakeholder as an individual or a group that has an impact on the organisation's objectives. Interestingly, originally for Freeman, following the objectives of the stakeholders was supposed to lead to maximisation of the company's profits. But already in his work Strategic management: A stakeholder approach (Freeman, 1984, p. 48) it was no longer a profit, but identifying and meeting the needs of stakeholders that became the main objective of the company. In the Polish literature, K. Obłój (2007, p. 184) defines stakeholders as institutions and organisations that meet two conditions: have their stake in the organisation's operation (i.e., in decisions and results) and are able to exert effective pressure. His concept distinguishes two types of stakeholders - internal and external.

Internal stakeholders are primarily owners/shareholders, employees, and managers. Shareholders, thanks to the funds invested in the development of the company, influence the selection of goals and the possibility of achieving them. Shareholders present their expectations to the management board, the lack of their 
implementation usually leads to personnel changes in the company. The owner, by selecting the management staff as well as appropriate incentive systems, is able to integrate the objectives of shareholders and managers. Most often, by making remuneration dependent on the level of profit, he or she effectively motivates managers to achieve the company's goals. Similar mechanisms are used in relations with employees. Employees are the value of the company or generate value themselves by performing the tasks assigned to them.

The second group is made up of external stakeholders, i.e., customers, suppliers, competitors, industry organisations or state institutions. Nowadays, the media that shape the image of a company and often create a good or bad demand climate cannot be omitted. Financial institutions supporting companies, customers or suppliers influence the ability to achieve the objectives of each of these groups. It should be stressed that each stakeholder group may be guided by its own particular interest, which is often in conflict with the interests of other groups and the objectives of the company itself.

The concept of stakeholders underpins the idea of Corporate Social Responsibility (CSR). CSR is defined as a philosophy of doing business, including building lasting, transparent relations with all stakeholders (Wołowiec, 2004, p. 3). According to this assumption, profit is not the only aim of the company but also a positive impact on the environment. The creation of three types of relations between the enterprise and its stakeholders, between the enterprise and the society and between the stakeholders and the society is necessary for the implementation of this approach (Pisz \& Łapuńka, 2017). We should agree with O. Bazzichi (2003, p. 496) that "Corporate Social Responsibility is the voluntary combination of social and economic issues in commercial activities and relationships with stakeholders, who are employees, customers, suppliers, the community in which the company operates." Therefore, it can be concluded after M. Rojek-Nowosielska (2011) that companies, as responsible members of local communities, have a large share in shaping their future.

The development of the CSR concept at the level of the entire economy is the idea of sustainable development. According to it, sustainable economic growth should meet the needs of present and future generations, as well as should have in mind the renewal of environmental resources (United Nations, 1983). The concept is based on a set of three integrated objectives: ecological, social and economic (Machowski, 2003). Moreover, companies should not only carry out activities within the framework of environmental or social initiatives, but they also should approach sustainability as a business strategy that generates concrete economic value (Brzozowski, 2010). 


\section{Review of the definitions of a sustainable enterprise}

As mentioned in the introduction, the aim of this article is to try to define, systematise and organise the concept of sustainable enterprise. Due to the purpose of the publication, a literature review (literature research, analysis and criticism of the literature) was adopted as the research method. It allows understanding a given research field, to get familiar with the main theories, their application, development and criticism (Zdonek, Hysa, \& Zdonek, 2016). The literature research consists of six stages, including: formulation of the problem, data collection, data evaluation, analysis and interpretation, presentation and indication of the direction of further actions (Randolph, 2009).

This analysis was carried out as part of the statutory research of SGH Institute of Human Capital in the period 12.2019-3.2020. ${ }^{1}$ Keywords were defined, i.e., sustainable organisation, sustainable enterprise. Next, ProQuest, Bazekon and Emerald databases were used to search for the keywords in titles and abstracts of articles in the years 2000-2019, obtaining 866 thousand, 437 and 49 thousand records, respectively. We selected 200 items with the highest number of quotations for the detailed analysis. Table 1 presents selected definitions proposed by Polish and foreign authors.

Table 1. Review of definitions of a sustainable organisation

\begin{tabular}{|l|l|}
\hline \multicolumn{1}{|c|}{ Source } & \multicolumn{1}{c|}{ Definition } \\
\hline Wrudzewski, Hejduk, Sankowska, & $\begin{array}{l}\text { A sustainable enterprise is the concept of the company } \\
\text { of 'tomorrow,' flexibly adapting to the constant turbulent } \\
\text { changes in the environment and able to function in chaos } \\
\text { and crisis. The company of the future concept and how it is } \\
\text { implemented are verified by the market. The key issues are an } \\
\text { in-depth analysis, intelligent and effective stimulation of the } \\
\text { changes of conditions in the company's environment to make } \\
\text { them as beneficial as possible for the company. This will allow } \\
\text { for sustainable development and prolonged market presence. }\end{array}$ \\
\hline Hart, Milstein (2003), 56-67. & $\begin{array}{l}\text { A sustainable enterprise, therefore, is one that contributes } \\
\text { to sustainable development by delivering simultaneously } \\
\text { economic, social, and environmental benefits - the so-called } \\
\text { triple bottom line. }\end{array}$ \\
\hline
\end{tabular}

\footnotetext{
1 Collegium of Business Administration, SGH Warsaw School of Economics.
} 


\begin{tabular}{|c|c|}
\hline Source & Definition \\
\hline Laszlo (2008), 15. & $\begin{array}{l}\text { A sustainable company becomes restorative - putting back on } \\
\text { balance more than it takes from the Earth, and doing good } \\
\text { for society. The employees of such a company are greatly } \\
\text { energised as a result of the strategy, feeling as never before } \\
\text { that through their jobs they are able to make a positive } \\
\text { contribution to the world they live in. Best of all, such } \\
\text { a company is poised for huge growth and profitability as it } \\
\text { meets the surging demand for market-based solutions to the } \\
\text { world's growing environmental and social challenges. }\end{array}$ \\
\hline Lozano (2008), 499-509. & $\begin{array}{l}\text { The triple bottom line is a specific element of the sustainable } \\
\text { organisations and includes economic (financial factors), } \\
\text { environmental (risk/requirement factors) and social } \\
\text { (human factors) issues which are solved through company's } \\
\text { collaboration with customers, suppliers, competitors, } \\
\text { communities and other stakeholders. Achieving all these } \\
\text { implies establishing milestones and short-term objectives and } \\
\text { encouraging learning, rationality, alignment motivation and } \\
\text { empowerment. }\end{array}$ \\
\hline Pabian (2017), 11-16. & $\begin{array}{l}\text { A sustainable enterprise operates on the basis of sustainable } \\
\text { resources. These resources include people, infrastructure, } \\
\text { durable and non-durable assets, as well as any outgoing } \\
\text { goods. Sustainable enterprises produce sustainable products. } \\
\text { In order for the company to be considered sustainable, all } \\
\text { functional areas of the strategy should be balanced, including } \\
\text { production, finance, logistics, marketing, sales, HR and other } \\
\text { functional areas. }\end{array}$ \\
\hline Parrish (2010), 510-523. & $\begin{array}{l}\text { A sustainable organisation is a formal entity that operates } \\
\text { through earned income and is capable of sustaining its own } \\
\text { activities while contributing to the development of the socio- } \\
\text { ecological system of which it is a part of. In other words, it } \\
\text { balances the need for economic growth with environmental } \\
\text { protection and social equity. On the other hand, sustainable } \\
\text { organisations are characterised by genuine visions that } \\
\text { integrate the need to earn a profit with the responsibility } \\
\text { to foster social justice and environmental protection. }\end{array}$ \\
\hline Przychodzeń (2011), 57-65. & $\begin{array}{l}\text { A sustainable enterprise is an economic entity that sees the } \\
\text { right combination of management of all the key aspects } \\
\text { of its business - financial, social, and environmental - as } \\
\text { a prerequisite for its long-term survival and profitability. }\end{array}$ \\
\hline
\end{tabular}

Source: own study.

The analysis has led to the identification of a set of common features for the definition of a sustainable enterprise. Sustainable enterprise ensures the environmental friendliness of its operating processes, while striving to meet the expectations of all stakeholders in order to prolong the chances of long-term market 
survival. Although the above definitions present the concept of a sustainable enterprise in a comprehensive way, the authors notice the definition gaps. First of all, the quoted authors do not determine whether a sustainable enterprise meets the expectations of stakeholders consciously and according to the chosen strategy, or whether the operations of a sustainable enterprise can simply be the result of accidental pressure. Secondly, the above-mentioned definitions do not sufficiently highlight the role of internal stakeholders in the context of the ability to replicate the company's resources. Thirdly, these definitions describe the ideal type of sustainable enterprise rather than setting limits - minimum conditions that an enterprise must meet to be recognised as sustainable. In order to achieve the cognitive goal of this article, a definition of a sustainable enterprise is proposed.

\section{Definition of a sustainable enterprise}

A sustainable enterprise is an organisation that can consciously meet the financial and non-financial (e.g., environmental) expectations of its stakeholders in the long term. This definition borrows a number of assumptions from the stakeholder theory (Freeman, 1984). First, the assumption of an organisation's accountability to its stakeholders, not only those 1) decisive, without whom the organisation cannot function, but also those 2) contractually related to the organisation through a contract and those 3) contextual who impact social recognition of the company (Rodriguez, Ricart, \& Sanchez, 2002). As stakeholders vary from organisation to organisation and their number can differ from several to several dozen, they are defined according to their type of expectations towards the company - financial and non-financial (Parmar, Freeman, Harrison, Wicks, Purnell, \& de Colle, 2010). Second, the assumption that the organisation must consciously negotiate and reconcile divergent stakeholder objectives. If, as Freeman (1979) presumes, a company's objective is to survive, it must develop an ability to monitor its environment, understand its interests and then consciously incorporate them into its long-term strategy. Therefore, important concepts in the presented definition are 'to consciously satisfy' (understood as the effect of internal processes in the organisation, not spontaneous actions under pressure) and 'long-term' (that assumes the rationality of actions taken in accordance with the long-term strategy of the company). Thus, attention is shifted from the analysis of activities oriented at selected stakeholders, carried out within the framework of individual functions of the enterprise, e.g., sustainable supply chain (Kołosowki \& Jóźwiak, 2019) or sustainable human resources (Bombiak, 2018), to the whole of the enterprise's activities and its sustainability. 
As companies take various initiatives to balance their activities, it seems appropriate to set minimum conditions which such an organisation must meet. Therefore, the definition is complemented by setting the boundaries of sustainability of the company - the limits of action are determined by compliance with applicable law, the ability to reproduce resources and the ability to generate value. These boundaries refer to the classic division proposed by the World Commission on Environment and Development lead by Brundtland (1987), who defined sustainable development in three dimensions - economic, social and environmental. In the proposed definition, the social dimension is divided into two: that relating to human resources and that relating to the social system. The former was combined with the environmental sphere to create a dimension of resource renewal (human, environmental and natural). The latter was called the dimension of legal compliance.

\section{Characteristics of the boundaries of a sustainable enterprise}

Legal compliance is a boundary which determines whether the company's activities do not exceed the framework, regulations and standards set by the state administration. Acting outside the legal framework weakens the position of the company and limits its ability to achieve its long-term objectives. This mechanism can be observed in the case of illegal activities aimed at obtaining a financial benefit, e.g., non-compliance with emission standards (cf. Volkswagen diesel gate scandal). Although they increase a company's profit in the short term, they lead to a loss of confidence from the state and consumers in the long term. This increases the organisation's transactional costs and reduces the possibility of improving product margins.

The ability to generate value is a boundary that determines whether the company's actions do not limit the chances of generating profit in the future and creating value in its environment. It should be stressed that a sustainable enterprise bears the costs of adjusting its activities to the changing expectations of its stakeholders in the short term in order to strengthen its position in the long term, as in the case of energy companies switching energy production to renewable sources (cf. Eon's strategy change). In this case, the value should not be understood as a financial gain only. It is also an intangible asset generated in relation to other business entities, e.g., through competition (Brandenburger \& Stuart, 1996). Therefore, an organisation that seeks to increase its financial profit and deteriorates its relations with the business environment cannot be called sustainable.

Resources reproduction ability is a boundary that determines whether or not a company's activities limit the number and quality of available resources, above all, human (i.e., the human capital of the company), natural (i.e., water or air) and 
environmental (i.e., diversity of species of fauna and flora). Even if their excessive use - leading to a shortage in the future - is beneficial to the organisation in the short term (e.g., increasing standards to the limits of feasibility for production workers), in the long term it reduces access to the resources, making the organisation unsustainable.

Figure 1. Boundaries of a sustainable organisation

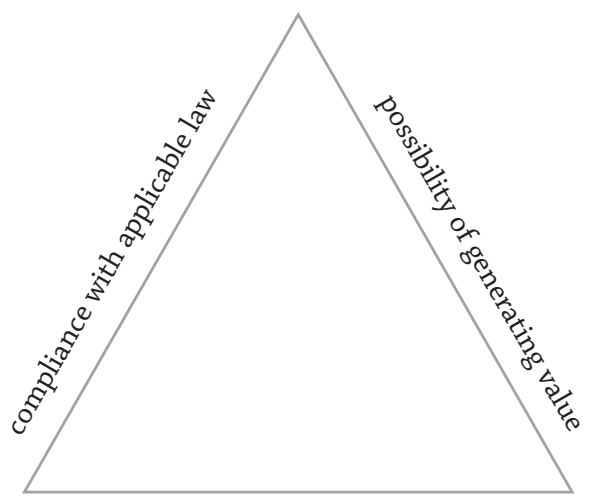

ability to reproduce resources

Source: own study.

\section{Relationship between the boundaries of a sustainable enterprise}

Boundaries set actions that make an entity no longer sustainable. It is also important to look at the interrelationships of these boundaries - how they jointly define the field of action for a sustainable enterprise. Three such relationships will be discussed below between 1 ) the ability to reproduce resources and possibility of generating value, 2) the ability to reproduce resources and compliance with applicable law, and 3) the compliance with applicable law and possibility of generating value.

A sustainable enterprise has the capacity to reproduce resources. Sustainable is, for example, the one that invests in employer branding in order to increase the pool of talent from which it will select future employees. Unsustainable is the one, for example, where employees communicate unfriendly corporate policies to people outside the organisation, limiting the number of people willing to work for the company. How much expenditure should the enterprise incur to strengthen its ability to reproduce its resources? It is determined by the limit to the possibility of generating value. If strengthening the ability to reproduce resources (e.g., through costly image 
campaigns in the media) leads, for example, to NPV value below 0 , the company should be considered as no longer sustainable (Ionescu-Somers \& Steger, 2008).

The relationship between the ability to reproduce resources and compliance with applicable law is well illustrated by the discussion on corporate citizenship. Zasuwa (2008) describes citizenship as a metaphor that indicates certain rights and obligations of a company towards society and the state. As Matten and Crane (2005) argue, such an approach is inappropriate because it would also involve the right to civil disobedience - thus, acting against the current law would be justified - in defence of human or environmental rights. Matten and Crane argue further that companies should not do so because it results in a violation of the legal order on which the survival of the company as a legal entity depends. Therefore, organisations can only take action within the framework of existing law, if they are to be sustainable and keep the capability of pursuing their interests in the long term. However, this does not just mean being subject to the law. As Matten and Crane point out, companies can also create conditions for their stakeholders to exercise their social, political, or civil rights.

A sustainable enterprise is the one that at least operates in accordance with applicable law. Much stronger restrictions are imposed by ethical organisations - those that are guided not only by the legal order but also by a narrowly defined set of values (Collier, 1998). It influences the shape of the organisation's activities and practices which starts from the selection of suppliers to employee evaluations. Not all ethical activities should be considered as characteristic for a sustainable enterprise - only those that do not limit the possibility of generating value. An example of this is Virgin Atlantic's policy, where fuel economy savings were donated to charity (Waytz, 2019). An airline can only be considered a sustainable enterprise if the reduction in fuel consumption does not adversely affect flight times and thus, the ability to compete with other airlines on the selected routes.

\section{Conclusion}

In the times when companies are increasingly trying to act to satisfy the interests of a variety of its stakeholders comprehensively, a definition of a sustainable enterprise is needed. The authors consider sustainable enterprises as those that can consciously meet the financial and non-financial expectations of their stakeholders over the long term. They also propose outlining the boundaries that organisations cannot cross if they want to be called sustainable.

The presented definition differs from those popular so far in the literature in that it does not define the ideal state to which organisations should strive. It 
defines boundaries - minimum conditions that companies must meet, at the same time leaving it up to these companies to decide strategically how much value they will create for individual stakeholders. Moreover, the proposed definition draws attention to the dimension of compliance with applicable law that is omitted in other definitions. These definitions, following the fashions created by consulting companies, pay attention primarily to the aspect of creating value for (local) communities and acting for the natural environment. However, in order to call a company sustainable, it is necessary to verify compliance with, e.g., employee rights. An organisation that supports environmental improvements while mobbing employees by forcing them to make excessive efforts cannot be called sustainable.

This definition calls for strong coordination of the various functions of the company - human resource management, communication, production, supply chain, etc. The authors of this publication recommend conducting research that will show how activities leading to sustainability at the level of the whole organisation are coordinated in these areas.

\section{References}

Bazzichi, O. (2003). Społeczna odpowiedzialność przedsiębiorstwa. Społeczeństwo. Studia, prace badawcze, dokumenty z zakresu nauki społecznej Kościoła, 55(3).

Bombiak, E. (2018). Zrównoważone zarząadzanie zasobami ludzkim jako wsparcie zrównoważonego rozwoju organizacji, In: Стратегические направления социальноэкономического и финансового обеспечения, материалы международной научно-практической конференции, Беларусь, Минск, 75-79.

Brandenburger, A.M., \& Stuart, H.W. (1996). Value-based business strategy. Journal of Economics \& Management Strategy, 5, 5-24. Retrieved form: https://doi.org/10.1111/ j.1430-9134.1996.00005.x

Brundtland, G. (1987). Report of the World Commission on the Environment and Development: Our Common Future. United Nations General Assembly document A/42/427.

Brzozowski, T. (2010). Zrównoważony rozwój organizacji - ujęcie praktyczne. Prace Naukowe Uniwersytetu Ekonomicznego we Wrocławiu, 377, 137-145.

Collier, J. (1998). Theorising the ethical organization. Business Ethics Quarterly, 8(4), 621-654.

Freeman, R.E., \& Chan, R. (1979, November). Stakeholder negotiations: Building bridges with corporate constituent. Management Review, 8-13.

Freeman, R.E. (1984). Strategic management: A stakeholder approach. Boston: Pitman Publishing Inc.

GlobeScan - SustainAbility. (2019). The 2019 GlobeScan / Sustainability Leaders Survey. Retrieved from: https://globescan.com/2019-sustainability-leaders-report/ 
Grudzewski, W.M., Hejduk, I.K., Sankowska, A., \&Wańtuchowicz, M. (2010). Sustainability w biznesie, czyli przedsiębiorstwo przyszłości - zmiany paradygmatów i koncepcji zarządzania. Warszawa: Poltext.

Hart, S.L., \& Milstein, M.B. (2003). Creating sustainable value. Academy of Management Perspectives, 17(2), 56-67.

Ionescu-Somers, A., \& Steger, U. (2008). Corporate sustainability management, In: A. Ionescu-Somers, U. Steger (Eds.), Business logic for sustainability: A food and beverage industry perspective. London: Palgrave Macmillan, 146-169.

Kołosowski, A., \& Jóźwiak, A. (2019). Zrównoważony łańcuch dostaw. Systemy Logistyczne Wojsk, 38, 129-140.

Laszlo, C. (2008). Sustainable value. Stanford: Stanford Business Books.

Lozano, R. (2008). Developing collaborative and sustainable organizations. Journal of Cleanear Production, 16, 499-509.

Machowski, J. (2003). Ochrona środowiska. Prawo i zrównoważony rozwój. Warszawa: ŻAK Wydawnictwo Akademickie.

Matten, D., \& Crane, A. (2005). Corporate citizenship: Towards an extended theoretical conceptualization. Academy of Management Review, 30, 166-179.

Obłój, K. (2007). Strategia organizacji. Warszawa: PWE.

Pabian, A. (2017). Zrównoważone przedsiębiorstwo jako rezultat zmian organizacyjnych. Przegląd Organizacji, 8(931), 11-16.

Parmar, B., Freeman, R., Harrison, J., Wicks, A., Purnell, L., \& de Colle, S. (2010). Stakeholder theory: The state of the art. The Academy of Management Annals, 4(1), 403-445.

Parrish, B.D. (2010). Sustainability - driven entrepreneurship: Principles of organization design. Journal of Business Venturing, 25, 510-523.

Pisz, I., \& Łapuńka, I. (2017). Istota i znaczenia zarządzania relacjami z interesariuszami projektu. Prace Naukowe, Uniwersytet Ekonomiczny w Katowicach, 296-308.

Przychodzeń, W. (2011). The concept of sustainable enterprise. Economics and organization of enterprise, 5, 57-65.

Randolph, J.J. (2009). A guide to writing the dissertation literature review. Practical Assessment Research and Evaluation, 14(13), 1-13.

Rodriguez, M.A., Ricart, J.E., \& Sanchez, P. (2002). Sustainable development and the sustainability of competitive advantage: A dynamic and sustainable view of the firm. Creativity and Innovation Management, 11, 135-146.

Rojek-Nowosielska, M. (2011). Społeczna odpowiedzialność biznesu a cel maksymalizowania zysku przez przedsiębiorstwa. Zeszyty Naukowe Uniwersytety Ekonomicznego we Wrocławiu, 156, 39-49.

The United Nations [UN] (1983). United Nations National Assembly Resolution no. 38/161 of December 19.

Waytz, A. (2019). The power of human: How our shared humanity can help us create a better world. New York: W.W. Norton Company.

Wołowiec, T. (2004). Społeczna odpowiedzialność przedsiębiorstwa nową formułą zarządzania. Ekonomika i Organizacja Przedsiębiorstw, 3, 3-11. 
Zasuwa, G. (2008). Co oznacza obywatelstwo przedsiębiorstw?. Prace Naukowe Uniwersytetu Ekonomicznego we Wrocławiu, Społeczna odpowiedzialność przedsiębiorstw, 5, 295-303.

Zdonek, I., Hysa, B., \&Zdonek, D. (2016). Publikacje przeglądowe w naukach o zarządzaniu - istota i tendencje. Zeszyty Naukowe Politechniki Śląskiej, 96, 519-533.

\section{Bartłomiej Brach}

PhD student at the Collegium of Business Administration at SGH Warsaw School of Economics. He is interested in the issues of the meaning of work, management of meaning in the organisation and positive organisational scholarship. e-mail address: bartek.brach@gmail.com

ORCID: 0000-0002-4746-8490

\section{Marcin Gul}

PhD student at the Collegium of Business Administration at SGH Warsaw School of Economics. His research interests concern sustainable development with a focus on strategic business management, with a particular emphasis on sales management. e-mail address: gul.marcin@gmail.com

ORCID: 0000-0002-4919-9634

\section{Grzegorz Kawecki}

PhD student at the Collegium of Business Administration at SGH Warsaw School of Economics. His main research interests are related to Human Capital Management in large organisations.

e-mail address: grzegorz.kawecki@dafna.pl

ORCID: 0000-0002-7716-2054

The authors had an equal contribution to this article. 